\title{
A Case Study of Teaching Methods, Approaches, and Strategies Found in a Critical Review on Applied Linguistics Course
}

\author{
Habibatul Azizah Al-Faruq \\ Universitas Negeri Malang \\ (habibahalfaruq@gmail.com)
}

\begin{abstract}
This study investigated the critical review on applied linguistics course teaching methods, approaches, and strategies which would be found in post graduate program in ELT in State University of Malang in the second semester. The lecturer is the teacher who is teaching critical review on applied linguistics course in offering E, class A. This study used one-site case study. Data was gathered from observations. The result of the study showed that the teacher relies on Communicative Language Teaching which was found in the classroom activities. Therefore, this paper critically reviews Intarapanich's article (2013) "Teaching Methods, Approaches and Strategies Found in EFL Classrooms: A Case Study in Lao PDR" on the basis of the nature methods, approaches, and strategies in the teaching EFL classrooms, the existing practice in the teaching of EFL, and for the investigation proposed that teacher should adapt learning activities, based upon student abilities and constraint in classroom setting.
\end{abstract}

Keywords: methods, approaches, strategies, applied linguistic course.

Teaching methods, approaches, and strategies cannot be separated in teaching and learning activities. There are many kinds of method, approach, and strategy. Every teacher has different style of method, approach, and strategy for teaching because the belief of the teacher to use them will influence the success of teaching and learning activities.

Anthony in Brown (2000) stated that method was described as an overall plan for systematic presentation of language based upon a selected approach. While for approach defines assumptions, beliefs, and theories about the nature of language and language learning (Richards and Rodgers in Brown, 2000). Teaching strategies refers to wisdom in selecting teaching approach, teaching method, techniques and activities in order to achieve teaching objectives.

In her study on "Teaching Methods,
Approaches and Strategies Found in EFL Classrooms: A Case Study in Lao PDR", Intarapanich (2013, p. 308) involved 5 English teachers from three different schools - one primary and two secondary schools. They were teachers at $3 \mathrm{rd}, 4 \mathrm{th}, 9 \mathrm{th}, 11 \mathrm{th}$, and 12 th grade levels. But in this case, the researcher did not mention the detail about background of each participant, just only the history of background of each participant that was collected through an interview as a part of data collection.

In Intarapanich (2013, p. 306) studies stated that back to age 1986, the English language has been increasingly important in Lao education according to the "Chinatakan Mai" (new way of thinking) policy, which represents a change from a centrally planned economy and Eastern bloc-oriented foreign policy toward a market economy and an omnidirectional foreign policy. Because of the 
implementation of the policy, a transit of people from other countries has increased the demand for English language learning in Lao PDR. And this statement supported by the data that found $81.2 \%$ of Lao secondary school students "strongly agree" that English is important.

The result of Intarapanich (2013) that learning English as a foreign language in the classroom in Lao schools were various and affinity the learners because of the teachers did not use monotones teaching methods, strategies, and approach. Not only that the teacher also provided teaching tools, such as flash cards, textbooks, worksheets, and chalkboard/ white board that played a major part in teaching and learning.

That study has inspired the present research. It was tempting to explore further findings in teaching methods, approaches, and strategies because every teacher has different style in teaching, moreover the teacher might be use post method that does not use certain procedure in applying itself.

This study focuses on classroom English language teaching in applied linguistics on emphasizing on major language teaching and learning methods, approaches, and strategies that used in State University of Malang in the second semester. And for major resources, this study used "Approach and Methods in Language Teaching" by Jack Richards and Theodore, "Methods and Approaches in Language Teaching in Brief" by Gültekin Boran, and "Teaching by Principles; an Interactive Approach to Language Pedagogy" by H. Douglas Brown. Those books categorized into nine different methods/ approaches/ strategies, namely the Oral Approach and Situational Language Teaching, the Grammar Translation Method (GTM), the Audio-Lingual Method (ALM), Communicative Language Teaching (CLT), the Total Physical Response (TPR), the Silent Way, Community Language Learning (CLL), Suggestopedia, and the Direct Method. Related those kinds of methods/ approach/ strategies, in Intrapanich study, there were little description of them.

The Oral Approach and Situational Language Teaching were emphasized on spoken language teaching in the beginning. The target language is the language of the classroom. New language points are introduced and practiced in situation. Related to the procedure, there are five steps (Richards and Theodore, 1986; 39), they are: pronunciation, revision (to prepare for new work if necessary), presentation of new structure or vocabulary, oral practice (drilling), reading of material on the new structure, or written exercise.

The Grammar Translation Method (GTM), the learning theory, deductive learning is essential. The teacher gives rules explicitly then the rules are reinforced with examples and exercises. Language theory: Language is for understanding the literature. Translation is the way to learn the language. Oral communication is not primarily important. Written language is superior to spoken language. Students also learn the structure of their own native language. Those who study a foreign language become more cultured and intellectual (Boran, 2010). So, the role of the teacher is strict authority. Classes are teacher centered. And for the students' role are the passive receivers of the new information. The teacher starts the activities and directs them. Students are supposed to memorize the rules and the new vocabulary with their meanings in their native language.

The Audio-Lingual Method learning is based on the principles of behaviorism (Mimeapproach). Habit Formation is essential. Rules are induced from examples. Explicit grammar rules are not given. Learning is inductive. Habit formation is actualized by means of repetitions and other mechanical drills. Language is based on descriptive linguistics. Every language is seen as its own unique system. The system is comprised of several different levels, i.e. phonological, morphological, and syntactic. There is a natural order of skills: 1) Listening, 2) Speaking, 3) Reading, and 4) Writing. Everyday speech and oral skills are important. Perfect pronunciation is required. Language is 
primarily for Oral Communication. And for the teacher's role is like an orchestra leader. $\mathrm{S} /$ he directs and controls the language behavior of the students. Teacher is a good model of the target language, especially for pronunciation and other oral skills. Meanwhile, students are imitators of the teacher as perfect model of the target language or the native speakers in the audio recordings.

Communicative Language Teaching (CLT) considered language is for communication. The goal of language teaching is to develop 'communicative competence'. Using the language appropriately in social contexts is important and communicative competence should be acquired. Students benefit from group work, pair work, group discussions, projects...etc. The teacher's role is as a facilitator of his/her students' learning. $\mathrm{He} / \mathrm{she}$ is a manager of classroom activities. He/she acts as an advisor and monitors students' performance. For students' role are as communicators. They are engaged in negotiating meaning actively. Students are responsible managers of their own learning.

Total Physical Response (TPR), language is primarily oral. It is just like the acquisition of native language. Learners first listen (silent period), then oral production starts. Oral communication is crucial. Skilful use of imperatives by the instructor can be helpful for the acquisition of many vocabulary items and grammatical structures. Asher views the verb and particularly the verb in the imperative as the central linguistic motif around which language use and learning are organized. For the teacher's role is as the director of all student behavior. And the students are followers of the teacher.

The Silent Way, in process of learning a new second language, is fundamentally different from L1 learning, L2 learning is an intellectual, cognitive process (Brown, 2007, p. 36). Richards and Rodgers (2001, p. 81) in Brown (2007, p. 29) adds theory of learning behind the Silent Way: 1) Learning is facilitated if the learner discovers or creates rather than remembers and repeats what is to be learned,
2) Learning is facilitated by accompanying (mediating) physical objects, 3) Learning is facilitated by problem solving involving the material to be learned.

Community Language Learning (CLL) represents the use of Counseling-Learning theory to teach languages. Community Language Learning draws on the counseling metaphor to redefine the roles of the teacher (the counselor) and the learners (the clients) in the language classroom (Richards and Rodgers, 1986, p. 113).

Suggestopedia, this method communication is a two-plane process. Language is the first of the two planes. In the second plane, there are factors, which influence the linguistic message (e.g. the way one dresses, non-verbal behaviors that affect the linguistic message). Students just relax and listen to them being read and later playfully practice the language during an 'activation' phase. Teacher is the authority. Learners learn better if they get the information from a reliable authority.

The Direct Method, there is a direct exposure to the target language, usually there is no translation is allowed. Here are some lists of principles and procedures in this method: 1) Classroom instruction was conducted exclusively in the target language, 2) Only everyday vocabulary and sentences were taught, 3) Oral communication skills were built up in a carefully graded progression organized around question and answer exchanges between teachers and students in small, intensive class, 4) Grammar was taught inductively, 5) New teaching points were introduced orally, 6) Concrete vocabulary was taught through demonstration, objects, and pictures; abstract vocabulary was taught by association of ideas, 7) Both speech and listening comprehension were taught, 8) Correct pronunciation and grammar were emphasized (Richards and Rodgers, 1986, p. 9). The teacher usually directs the interactions but he/she is not as dominant as in GTM. Sometimes acts like a partner of the students. And for students are active participants. Sometimes pair works take place. 
Even the teacher takes roles in activities.

Every methods/ approach/strategies has strengths and weaknesses, however; teachers play important role in teaching the materials itself. The teachers know well which one to use, and when to use it, because they themselves that know the students' characters in the class.

Based on those explanations above, the research question was formulated as follows: which teaching methods, approaches, and strategies were found in Applied Linguistics courses?

\section{Method}

This study, conducted at one class specifically Applied Linguistics course in State University of Malang, especially in the academic year 2013/2014 class A offering E, that consisted of 22 students. This course held one meeting in a week on Thursday, investigated the EFL teaching methods/ approaches/ strategies through observations of teacher's teaching and taking pictures of the activities in the classroom.

To obtain the data, the researcher used direct observation and takes some pictures. Data collection took approximately 5 weeks during second semester. Teacher who participated in the study were observed directly in his teaching. During the data collection, the researcher as a participated observer noted downs all teaching and learning activities in chronological order on observation form. In order to strengthen the brief handwriting notes, take a picture was used.

\section{Result and Discussion}

According to observations, the lesson activities found in this course were various, mostly provided the students more opportunities to communicate, use the language, interact with others, and work collaboratively. Communicative Language
Teaching was used in Applied Linguistics course in State University of Malang. Generally, Communicative Language Teaching contains social interaction activities, including discussion and conversation sessions, role plays, simulations, improvisations, and debates.

Relating to the findings, in Intarapanich's study did not mention any difficulties in using CLT in that class. But only on lower secondary level, conversation discussion dialogues and role playing were barely appeared in the classroom while the first language appeared many times during conversation between teachers and students. By contrast, in Li's study (1998) confirmed that the teachers encountered difficulties in using CLT practices in their classes. That also occurred in Ozsevik's study (2010). The difficulties reported by the Korean teachers were divided into the following four categories:

1. Difficulties caused by teachers:

a. Deficiency in spoken English,

b. Deficiency in strategic and sociolinguistic competence,

c. Lack of training in CLT,

d. Few opportunities for retraining in CLT,

e. Misconceptions about CLT,

f. Little time for and expertise in material development

2. Difficulties caused by students:
a. Low English proficiency,
b. Little motivation for communicative competence,
c. Resistance to class participation

3. Difficulties caused by the educational system:
a. Large classes,
b. Grammar-based examinations,
c. Insufficient funding,
d. Lack of support

4. Difficulties caused by CLT itself:
a. CLT's inadequate account of EFL teaching
b. Lack of effective and efficient 
assessment instruments. (Li, 1998, p. 687)

Communicative Language Teaching was found, in the first until fifth meetings, the teacher asked one or two of the students to read a paragraph in the handbook, after that the teachers divided the students into several groups which used Numbered Head Together to classify them. In reading session itself, reading aloud strategy was found to stimulate the student's readers and listener's imaginations and emotions and to make difficult text understandable, and also the teacher gave a brief explanation. In Intarapanich's study (2013) for reading aloud here, the teacher asked read volunteered. Before that the teacher distributed a piece of paper (work sheet) for each student which was designed of list of topics per group. Reading aloud, lecture, text book and worksheet are sample of direct instruction strategies. And after that the teacher let the students to discuss the topic with the members of the group. Then, after the time of discussion was over, the teacher asked the first group to take turn to present about the topic that had been given before. Discussion and Numbered Head Together (NHT) are examples of cooperative strategies. In this session, another groups paid attention to the presentation and also allowed to ask to the presenters. Oral presentation includes one of activities based strategies. The advice and answer the questions were presented while the students did their presentations. Questioning was a tool to inquire the information and asked as follow up questions for the students to clarify the answer in details. Questioning process includes one of inquiry and research models. It means using the procedures where learners work in pairs or groups employing available language resources in problem solving tasks. Many strategies that were found in Communicative Language Teaching itself such as pair and group work, role playing, grammar and pronunciation in focus activities and brainstorming, summarizing, and questioning. For the basic teaching equipment that were used in this course were also various, such as textbook, worksheet, white board, LCD, laptop or notebook, sound system, video. Not only that the students were also modified their learning, in other words, the learner used audio video, realia, song in order to make easier the comprehending of the listeners when they were explaining their topic. After the students finished their presentation, at the end of meeting the lecturer gave some comments or explanations about the topic that has been discussed. But in Intarapanich's study (2013), she found that audio devices, such as media players and speakers were not available. Because of that, traditional teaching methods were also used in the class.

Because the teacher is not only as someone who teaches in the class, the teacher is also as a facilitator in Communicative Language Teaching. The teacher sometimes guided students in their assignments such as correcting mistakes, clarifying things that students did not understand fully, and motivating. In Intarapanich's study (2013) also added that an ideal EFL instructor should be creative, friendly, caring, polite, and adaptable. It means that, an ideal EFL instructor should also a positive attitude toward the teaching profession. Those are the suggestion from that study.

\section{Conclusion}

Communicative Language Teaching (CLT) was the dominant approach used in EFL class especially in Applied Linguistics course in State University of Malang. The activities in the classroom were various such as reading aloud, brainstorming, group work, songs, presentations, discussion, questioning, and summarizing. These types of activities provided the students more opportunities to communicate and use the target language effectively 


\section{References}

Boran, G. (2010). Methods and Approaches in Language Teaching in Brief.

Brown, H. D. (2007). Teaching by Principles: An Interactive Approach to Language Pedagogy, 3rd Ed. San Francisco: Pearson Education.

Richards, J. \& Rodgers, T. (1986). Approaches and Methods in Language Teaching. New York: Cambridge University Press.

Intarapanich, C. (2013). Teaching Methods Approaches and Strategies Found in EFL Classrooms: A Case Study in Lao PDR. Thailand: Language Center, Udon Thani Rajabhat University. Social and Behavioral Sciences 88: 306-311.

Ontario Curriculum Unit Planner. (2002). Teaching/Learning Strategies Companion. Queen's Printer for Ontario.

Li, D. (1998). It's always more Difficult than You Plan and Imagine": Teachers' Perceived Difficulties in Introducing the Communicative Approach in South Korea. TESOL Quarterly, 32(4), pp. 677703 in Ansarey, D. 2012. Communicative Language Teaching in EFL Contexts: Teachers Attitude and Perception in Bangladesh. ASA University Review, Vol. 6, No. 1.

Ozsevik, Z. (2010). The Use of Communicative Language Teaching (CLT): Turkish EFL Teachers' Perceived Difficulties in Implementing CLT in Turkey. University of Illinois at Urbana-Champaign. 